\title{
PENEGAKAN HUKUMAN MATI TERHADAP PEMBUNUHAN BERENCANA
}

\author{
Widhy Andrian Pratama \\ Mahasiswa Program Magister Ilmu Hukum, Pascasarjana Universitas Muslim Indonesia, Makassar \\ *Email Corresponding Author: adrianwidhy@yahoo.com \\ CP: 081344860522
}

Received: 2 Oktober 2019

Accepted: 8 Oktober 2019

\begin{abstract}
Abstrak. Penelitian ini bertujuan untuk menganalisis penegakan hukuman mati terhadap pembunuhan berencana dan mengkaji faktor-faktor penghambat dari penegakan hukuman mati terhadap pelaku pembunuhan berencana. Metode penelitian yang digunakan dalam penelitian ini adalah tipe penelitian hukum normatif/ doktrinal (normative legal research) yaitu tipe penelitian yang dilakukan dengan cara mengkaji peraturan perundang-undangan yang diterapkan terhadap suatu permasalahan hukum tertentu. Hasil penelitian ini menyatakan bahwa penegakan hukuman mati haruslah diberlakukan terhadap pembunuhan berencana karena, penerapan hukuman mati tidaklah bertentangan dengan Hak Asasi Manusia yang banyak dipersoalkan selama ini, sedangkan faktor-faktor yang menjadi penghambat dilaksanakan eksekusi mati tersebut antara lain: dari aspek yuridisnya, Kebijakan Pemerintah, dan Lemahnya koordinasi antara penegak hukum. Adapun saran yang diberikan kepada pembuat undang-undang agar melakukan pembaharuan terhadap KUHP terkhusus lagi mengenai Pasal tentang Pembunuhan Berencana, agar sebaiknya dicantumkan dalam pasal ataupun penjelasan tersebut tentang kualitas dan kuantitas yang didasarkan pada alternatif hukuman yang diberikan. Selanjutnya merekomendasikan mengenai batasan dan waktu dalam hal pengajuan remisi dan grasi terhadap hak terpidana matiyang melakukan kejahatan pembunuhan berencana karena hal tersebut dapat menjadi celah bagi para terpidana.
\end{abstract}

Kata Kunci:

Penegakan Hukum;

Pembunuhan Berencana;

Hukuman Mati.

artikel dengan akses terbuka dibawah lisensi CC BY -4.0

\section{PENDAHULUAN}

\section{A. Latar Belakang Masalah}

Proses perkembangan pidana mati dariabad keabad sampai padajaman modernsaat sekarang ini dapat dianggap sebagai salah satu indikasi atau ukuran mengenai arah kemajuan dari perkembangan kehidupan budaya manusia dari tahun ke tahunnya. Pelaksanaan hukuman mati sangatlah bervariasi tergantung pada masyarakat atau negaranya, tradisi, tingkat kepercayaan, tingkat kebudayaan, dan lain sebagainya. ${ }^{1}$

${ }^{1}$ Jacob Elfinus Sahetapy dalam Todung Mulya Lubis \& Alexander Lay. Kontroversi Hukuman Mati: Perbedaan Pendapat Hakim Konstitusi. Jakarta: Kompas, 2009, hlm. 220. 
Perkembangan pemidanaan hukuman mati di Indonesia sepatutnya tidak terlepas dari struktur sosial-budaya masyarakat, yang menyangkut nilai-nilai keadilan yang hidup dan berkembang di tengah masyarakat, mengikuti kemajuan ilmu pengetahuan dan teknologi yang diselaraskan dengan pola pandangan kebijakan hukum yang dirumuskan dalam peraturan perundang-undangan. Mereka yang tidak menyetujui hukuman mati harus memiliki argumentasi yang komprehensif, logis, dan dapat dipertanggungjawabkan. Mungkin tidak jadi soal mengganti hukuman mati dengan hukuman lainnya yang sama beratnya. ${ }^{2}$

Hukum diciptakan untuk mengatur agar kepentingan yang berbeda-beda antara pribadi, masyarakat, dan negara dapat dijamin dan diwujudkan tanpa merugikan semua pihak. ${ }^{3}$ Maka untuk itulah dalam mengatur hubungan hukum dan masyarakat maka perlu diadakannya suatu kodifikasi hukum yang mempunyai tujuan luhur, yaitu menciptakan kepastian hukum dan mempertahankan nilai keadilan dalam subtansi hukum tersebut. ${ }^{4}$ Penerapan sanksi dalam penegakan hukum untuk mengatur seseorang sebagai subyek hukum haruslah memiliki rasa perikemanusiaan dalam menghargai harkat dan martabat hidup seseorang sebagaimana yang telah disebutkan di dalam Pembukaan Undang-Undang Dasar Negara Republik Indonesia Tahun 1945 (UUD NRI Tahun 1945). Penerapan sanksi hukum sebagai akibat dari adanya pelanggaran ketentuan undang-undang telah menciptakan adanya perdebatan sampai dengan saat ini. ${ }^{5}$

Pelaksanaan hukuman mati di Indonesia menjadi bahan pembicaraan yang cukup aktual dan polemik yang berkepanjangan bagi negara-negara yang beradap. Hal ini didasari pada penerapan hukuman mati yang dinilai tidak sesuai dengan falsafah negara yang menganut paham Pancasila, yang selalu menjunjung tinggi rasa kemanusiaan yang adil dan beradab. ${ }^{6}$ Namun dalam kenyataannya penerapan hukuman mati sampai detik di indonesia masih saja dipertahankan dan diterapkan dalam sistem hukumnya. ${ }^{7}$ Hukuman mati diperlukan untuk kepentingan masyarakat. Pendapat ini didasarkan pada keyakinan bahwa semua negara mempunyai hak mempertahankan atau membela diri, yang dapat pula berarti bahwa bisa mengesahkan penggunaan kekerasan terhadap individu. ${ }^{8}$

Hal tersebut nampak dari berbagai peraturan yang tercantum dalam Kitab Undang-Undang Hukum Pidana (KUHP) dan mengancam Pembunuhan Berencana dengan ancaman pidana mati. ${ }^{9}$ Keterkaitan hukuman mati dengan Hak Asasi Manusia (HAM) sangatlah erat, hal ini didasarkan pada suatu argumentasi bahwa penjatuhan hukuman mati terkait erat dengan hak yang paling asasi bagi manusia. Dalam konteks penjatuhan hukuman mati terhadap pelaku kejahatan yang

\footnotetext{
${ }^{2}$ Bambang Poernomo dalam Yon Artiono Arba'i. Aku Menolak Hukuman Mati: Telaah Atas Penerapan Pidana Mati. Jakarta: Kepustakaan Populer Gramedia, 2012, hlm. 7.

${ }^{3}$ Budi Suhariyanto. "Aspek Hukum Peninjauan Kembali Lebih dari Satu Kali dalam Perkara Pidana (Perspektif Penegakan Keadilan, Kepastian dan Kemanfaatan Hukum)." Jurnal Hukum dan Peradilan, Mahkamah Agung RI, vol. 4, no. 2 (2015): hlm. 339.

${ }^{4}$ Andi Hamzah, dan A. Sumangelipu dalam Hukman Reni. Hukuman Mati di Indonesia. Jakarta: Swakelola, 2015, hlm. 4 .

${ }^{5}$ Bambang Sugeng Rukmono. Hakikat Pelaksanaan Hukuman Mati Ditinjau dari Perspektif Hak Asasi Manusia. Bandung: PT. Citra Aditya Bakti, 2012, hlm. 13.

${ }^{6}$ M. Zen Abdullah. "Pelaksanaan Hukuman Mati di Indonesia Telaah dalam Konteks Hak Asasi Manusia." Jurnal Ilmiah, Universitas Jambi (2009): hlm. 61.

${ }^{7}$ Ibid.

${ }^{8}$ Yon Artiono Arba'i. 2012. Op. Cit., hlm. 3.

${ }^{9}$ Saptono Rahardjo, ed. 3 Kitab Undang-Undang Hukum: KUHPer, KUHP, KUHAP Beserta Penjelasannya. Jakarta: PT. Bhuana Ilmu Populer, 2017, hlm. 707.
} 
dilakukan dalam keadaan tertentu haruslah dikaji secara mendalam, mengingat penjatuhan hukuman mati merupakan pidana yang terberat dalam arti pelaku akan kehilangan nyawanya yang merupakan sesuatu hak yang tak ternilai harganya. ${ }^{10}$

HAM adalah seperangkat hak yang melekat pada keberadaan manusia sebagai makhluk Tuhan Yang Maha Esa dan merupakan anugerah yang wajib dihormati, dijunjung tinggi dan dilindungi oleh negara, hukum, Pemerintah dan setiap orang demi kehormatan serta perlindungan harkat dan martabat manusia. ${ }^{11}$ Setiap HAM menimbulkan kewajiban dasar dan tanggung jawab untuk di hormati secara timbal balik dan tugas pemerintah untuk melindungi, memajukan dan menegakkannya. Di dalam UUD NRI Tahun 1945 sebagai Konstitusi negara, terdapat rumusanrumusan tentang HAM. Hal ini dapat ditemukan di dalam pembukaan maupun di dalam batang tubuh, dengan adanya rumusan tersebut berarti negara mengakui adanya prinsip perlindungan hukum terhadap HAM. ${ }^{12}$ Pengakuan terhadap HAM di Indonesia dapat terlihat dalam Pasal 1 Undang-Undang Nomor 39 Tahun 1999 tentang Hak Asasi Manusia (UU No. 39 Tahun 1999) yang memberikan batasan tentang HAM sebagai seperangkat hak yang melekat pada hakikat dan keberadaan manusia. ${ }^{13}$

\section{B. Rumusan Masalah}

Berdasarkan latar belakang masalah tersebut di atas, maka dirumuskan permasalahan dalam penelitian ini adalah: Sejauh mana penegakan hukuman mati terhadap pembunuhan berencana, dan apakah faktor penghambat penegakan hukuman mati terhadap pembunuhan berencana?

\section{METODE}

Tipe penelitian yang penulis pergunakan di dalam penelitian ini adalah tipe penelitian hukum normatif/doktrinal (normative legal research) yaitu tipe penelitian yang dilakukan dengan cara mengkaji peraturan perundang-undangan yang diterapkan terhadap suatu permasalahan hukum tertentu.

\section{HASIL DAN PEMBAHASAN}

HAM juga menekankan terhadap beberapa prinsip dalam penegakan, misalnya yaitu: inherent (melekat), inalienable (tidak dapat dicabut), ${ }^{14}$ indivisible (tidak dapat diwakilkan), interrelated (saling berhubungan), equality (mendorong persamaan hak), non-discrimination (tidak ada diskriminasi), Namun prinsip yang terpenting dan melengkapi segala prinsip tersebut diatas adalah prinsip Universalisme yang merupakan jantung dari HAM yang bersifat internasional. ${ }^{15}$

Dalam tataran konseptual, HAM mengalami proses perkembangan yang sangat kompleks. HAM merupakan puncak konseptualisasi dari manusia tentang dirinya

\footnotetext{
${ }^{10}$ Abdur Rahim, Asruddin Azwar, Muhammad Hafiz, \& Satrio Wirataru. Hukuman Mati: Problem Legalitas \& Kemanusiaan. Malang: Intrans Institute, 2015, hlm. 54 - 57.

${ }^{11}$ Andrey Sujatmoko. Hukum HAM dan Hukum Humaniter. Jakarta: PT. Raja Grafindo Persada, 2015, hlm. 26.

${ }^{12}$ Tim Redaksi BIP, ed. Undang-Undang Dasar Negara Republik Indonesia Tahun 1945. Jakarta: PT. Bhuana Ilmu Populer, 2016, hlm. 199.

${ }^{13}$ Undang-Undang Republik Indonesia Nomor 39 Tahun 1999 tentang Hak Asasi Manusia. Lembar Negara Republik Indonesia No. 165 Tahun 1999. Tambahan Lembar Negara No. 3886.

${ }^{14}$ Habib Shulton Asnawi. "Hak Asasi Manusia Islam dan Barat: Studi Kritik Hukum Pidana Islam dan Hukuman Mati." Supremasi Hukum, vol. 1, no. 1 (2012): hlm. 25 - 48.

${ }^{15} \mathrm{Al}$ Khanif, Herlambang P. Wiratraman, \& Manunggal Kusuma Wardaya, eds. Hak Asasi Manusia: Dialektika Universalisme vs Relativisme di Indonesia. Yogyakarta: LKiS, 2017, hlm. 31.
} 
sendiri, oleh sebab itu jika disebutkan sebagai suatu konsepsi maka berarti pula sebagai upaya maksimal dalam melakukan formulasi pemikiran strategis tentang hak dasar yang dimiliki oleh manusia. ${ }^{16}$

HAM yang dianut Indonesia pada dasarnya bersumber dari Pancasila sebagai falsafah bangsa dan negara. Secara konseptual HAM yang terkandung di dalam Pancasila mengakomodasi aspek-aspek kemanusiaan sebagai individu dan makhluk sosial. Pengakuan tantang HAM secara prinsipil tercermin di dalam sila kedua (Pancasila).

Konsep dasar tentang HAM yang bersifat abstrak perlu dijabarkan dalam bentuk yang lebih konkrit lagi, sehingga mempunyai kekuatan hukum dalam pelaksanaannya. Pelaksanaan HAM sangat tergantung dari Good Will penguasa yang meletakkan lembaga yang legal dan mempunyai kekuatan hukum tetap yang sifatnya memaksa. ${ }^{17}$ Substansi HAM dapat dikaji dengan menggunakan dua pendekatan, yaitu pendekatan rectitude yang menekankan pada standar perilaku (Standard of Conduct) yakni apakah yang kita lakukan itu benar ataukah salah sehingga mewajibkan orang tersebut tunduk pada standar perilaku yang telah ditentukan. Sedangkan pendekatan entitlement yang mengarahkan perhatian kepada pemilik hak dalam arti apakah seseorang yang memiliki hak dapat dengan leluasa memiliki dan menggunakannya atau tidak, hal yang demikian tersebut berkaitan dengan kewajiban. ${ }^{18}$

Dalam konteks HAM, negara menjadi subyek hukum yang utama sebab negara merupakan entitas utama yang bertanggung jawab melindung, menegakkan, dan memajukan HAM. Dalam hukum dan HAM pemangku hak (rights holder) adalah individu, sedangkan pemangku kewajiban (duty bearer) adalah negara. Negara memiliki tiga kewajiban generik terkait HAM, yaitu menghormati (obligations to respect), melindungi (obligations to protect), dan memenuhi (obligations to fulfill. Individu di sisi lain diikat dengan tidak mengganggu HAM orang lain. ${ }^{19}$

Dokumen pertama yang secara resmi memberikan penghormatan dan perlindungan terhadap HAM adalah Bill of Right. Ketentuan tersebut lahir dari reaksi atau revolusi tanpa adanya pertumpahan darah (glorious revolutions) pada tahun 1688, untuk menundukkan monarki di bawah kekuasaan modern parlemen inggris. Dalam ketentuan tersebut diatur tentang hak-hak dan kebebasan wara negara yang menentukan adanya pergantian Raja. ${ }^{20}$ Permasalahan tentang HAM bukanlah merupakan suatu permasalahan yang baru bagi masyarakat dunia, karena isu tentang HAM sudah mulai dilontarkan semenjak lahirnya Magna Charta di Inggris pada tahun 1215 sampai dengan lahirnya Piagam Perserikatan Bangsa-Bangsa tentang Hak Asasi Manusia yaitu, "Universal Declaration of Human Right" pada tanggal 10 Desember 1948, patut pula dikemukakan di sini bahwa jauh sebelum lahirnya magna charta di Inggris, sebenarnya di dunia Islam telah lebih dahulu ada suatu Piagam tentang HAM yang dikenal dengan Piagam Madinah di Madinah pada tahun 622 SM, yang memberikan adanya jaminan tentang perlindungan HAM bagi penduduk madinah yang terdiri dari berbagai suku dan agama ${ }^{21}$

\footnotetext{
${ }^{16}$ Majda El Muhtaj. Hak Asasi Manusia dalam Konstitusi Indonesia: Dari UUD 1945 Sampai dengan Perubahan UUD 1945 Tahun 2002. Jakarta: Kencana Prenada Media Group, 2017, hlm. 2.

${ }^{17}$ Yasin Tasrif. "Hak Asasi Manusia dalam Kerangka Hukum Nasional Indonesia". Makalah dipresentasikan pada Lokakarya Integrasi Materi HAM ke dalam Mata Kuliah Umum. Semarang: Universitas Diponegoro, 1971.

${ }^{18}$ Muhammad Ashri. Hak Asasi Manusia: Filosofi, Teori \& Instrumen Dasar. Makassar: CV. Social Politic Genius (SIGn), 2018, hlm. 75.

${ }^{19}$ Ani W. Soejipto, ed. HAM dan Politik Internasional: Sebuah Pengantar. Jakarta: Yayasan Obor Indonesia, 2015, hlm. 182.

${ }^{20}$ Bambang Waluyo. Penegakan Hukum di Indonesia. Jakarta: Sinar Grafika, 2015.

${ }^{21}$ Rozali Abdullah \& Syamsir. Perkembangan HAM dan Keberadaan Peradilan HAM di Indonesia. Jakarta: Ghalia Indonesia, 2002, hlm. 9.
} 
HAM adalah hak dasar atau kewarganegaraan yang melekat pada individu sejak ia lahir secara kodrati yang diberikan langsung dari Tuhan Yang Maha Esa yang tidak dapat dirampas dan dicabut keberadaannya serta wajib dihormati, dijunjung tinggi dan dilindungi oleh negara, hukum, pemerintah dan setiap orang demi kehormatan dan perlindungan harkat martabat manusia. HAM meliputi hak sipil, politik, sosial, ekonomi dan hak untuk hidup dalam lingkungan yang sehat. Selain dari hal tersebut di atas, Indonesia wajib melaksanakan adanya perlindungan dan penegakan $\mathrm{HAM}^{22}$

Rumusan tentang HAM dapat kita temukan dalam beberapa aturan hukum, sekaligus mengandung pengertian tentang HAM itu sendiri, di antaranya dalam UU No. 39 Tahun 1999 tentang Hak Asasi Manusia, dan dalam Undang-Undang Nomor 26 Tahun 2000 (UU No. 26 Tahun 2000) tentang Pengadilan Hak Asasi Manusia, yang mana disebutkan bahwa:

"Hak asasi manusia adalah seperangkat hak yang melekat pada hakekat dan keberadaan manusia sebagai makhluk Tuhan yang Maha Esa dan merupakan anugerah-nya yang wajib di hormati, dijunjung tinggi, dan di lindungi oleh negara, hukum, pemerintah dan setiap orang demi kehormatan serta perlindungan harkat dan martabat manusia."

Selanjutnya dalam Pasal 1 butir 1 UU No. 26 Tahun 2000, HAM diberi definisi sebagai berikut:

"Seperangkat hak yang melekat pada hakikat dan keberadaan manusia sebagai makhluk Tuhan Yang Maha Esa dan merupakan anugerahnya yang wajib di hormati, dijunjung tinggi dan di lindungi oleh agama, hukum, pemerintah dan setiap orang demi kehormatan serta perlindungan harkat dan martabat manusia".

Berdasarkan pengertian tentang HAM yang tercantum dalam rumusan undang-undang di atas, sangat jelas kita jabarkan bahwa HAM di indonesia memiliki karakteristik tersendiri, yakni memiliki aspek teologis yang cukup kuat, yang mana menyatakan bahwa HAM adalah suatu pemberian Tuhan yang kemudian melekat pada diri tiap manusia. ${ }^{23}$

Peraturan perundang-undangan yang saat ini berlaku di indonesia terdapat berbagai macam jenis hukuman, satu di antaranya ialah hukuman mati. Hukuman mati (death penalty) merupakan jenis hukum yang paling tua di dalam sejarah kehidupan masyarakat, disamping hukuman penjara, samping itu juga posisi hukuman mati berada pada bagian yang khusus, tidak menjadi satu dengan pidana pokok lainnya dan selalu diancamkan secara alternatif, juga didasarkan pada pemikiran bahwa dilihat dari tujuan pemidanaan dan tujuan diadakannya hukum pidana (sebagai salah satu sarana ("Kebijakan Kriminal" dan "Kebijakan Sosial"), ${ }^{24}$ hukuman mati pada hakekatnya memang bukanlah sebagai sarana utama (sarana pokok) untuk mengatur, menertibkan dan memperbaiki masyarakat, akan tetapi hukum mati hanya bisa di jadikan sebagai sarana yang bersifat pengecualian. Indonesia termasuk ke dalam 63 negara yang dalam hukum positifnya masih memberlakukan hukuman mati bagi tersangka tindak pidana kriminal tertentu (extra ordinary crime).

\footnotetext{
${ }^{22}$ Mulyati Pawennei \& Amiruddin. Hak Asasi Manusia: Sejarah dan Perkembangannya di Indonesia. Makassar: Alauddin University Press, 2017, hlm. 13.

${ }^{23}$ Ramdlon Naning dalam Widiada Gunakaya. Hukum Hak Asasi Manusia. Yogyakarta: CV. Andi Offset, 2017, hlm. 143.

${ }^{24}$ Fernandes Edi Syahputra Silaban, Liza Erwina, \& Mahmud Mulyadi. "Kebijakan Hukum Pidana Terhadap Pengaturan Tindak Pidana Narkotika di Indonesia." Jurnal Mahupiki, Universitas Sumatera Utara, vol. 1, no. 1 (2013): hlm. 4.
} 
Pembenaran terhadap hukuman mati di dalam hukum positif di indonesia secara yuridis-normatif dapat dirujuk pada ketentuan-ketentuan dalam Pasal 10 KUHP, yang menyatakan bahwa hukuman mati sebagai jenis pidana pokok yang masih berlaku di indonesia dan masih tetap di pertahankan dalam sistem hukumnya. ${ }^{25}$ Keberadaan pidana mati dalam sistem perundang-undangan di indonesia tercantum di KUHP maupun pada regulasi-regulasi lainnya". Di antaranya, yakni tercantum pada delik perbuatan makar Pasal 104 KUHP, dalam delik Pembunuhan Berencana yang tercantum dalam Pasal 340 KUHP dan dalam regulasi lain yang sifatnya Lex Specialist, yakni delik pengedaran Narkoba yang memberikan sanksi pidana mati, yang mana hal ini tercantum dalam Pasal 113 ayat (2) dan 114 ayat (2), Undang-Undang Nomor 35 Tahun 2009 (UU No. 35 Tahun 2009) tentang Narkotika dan Undang-Undang Nomor 9 Tahun 2013 (UU NO. 9 Tahun 2013) tentang Pencegahan dan Pemberantasan Tindak Pidana Pendanaan Terorisme, ke semuanya itu menurut perspektif hukum pidana Indonesia masuk ke dalam kategori kejahatan luar biasa.

Negara dalam perspektif HAM diposisikan untuk melindung hak asasi manusia dan bukan sebaliknya, melainkan negara yang sering kali melakukan pelanggaran. Gagasan perlindungan HAM dari negara dikonstruksikan berdasarkan konsep hubungan kontraktual antara negara dengan masyarakatnya dimana penguasa diberikan kewenangan untuk mengatur serta membatasi hak relatif dari individu anggota masyarakatnya, namun negara tidak memiliki kewenangan atas HAM, karena tidak pernah diserahkan oleh masyarakat ke negara. Karena hal-hal tersebut terdapat hakhak yang melekat pada individu anggota masyarakat yang berlaku secara universal dan tidak dapat dikesampingkan dalam keadaan apapun dan negara harus menghormati serta melindunginya. ${ }^{26}$ Konsep HAM yang universal berpandangan bahwa HAM merupakan hak-hak kodrati yang dimiliki oleh manusia sejak lahir. Terkait dengan konsep HAM tersebut, UU No. 39 Tahun 1999 mendefinisikan HAM sebagai seperangkat hak yang melekat pada hakekat keberadaan manusia sebagai makhluk Tuhan Yang Maha Esa dan merupakan anugerah yang wajib di hormati, dijunjung tinggi dan di lindungi oleh negara, hukum, pemerintah dan setiap orang demi kehormatan serta perlindungan harkat dan martabat manusia.

Ketentuan hukum mengenai HAM pada intinya menjamin hak yang paling mendasar dari semua hak yang dimiliki oleh manusia yaitu hak hidup sebagaimana termuat di dalam Pasal 5 dan 8 Deklarasi HAM.

Hak hidup bahkan di sertakan penegasannya dengan kategori hak lainnya sebagai hak yang tidak boleh dikurangi di dalam kondisi apapun sebagaimana diatur di dalam Pasal 281 ayat (1) UUD NRI Tahun 1945 yang berbunyi:

"Hak untuk hidup, hak untuk tidak disiksa, hak kemerdekaan pikiran dan hati nurani, hak beragama, hak untuk tidak diperbudak, hak untuk diakui sebagai pribadi di hadapan hukum, dan hak untuk tidak dituntut atas dasar hukum yang berlaku surut adalah hak asasi manusia yang tidak dapat dikurangi di dalam keadaan apa pun".

UUD NRI Tahun 1945 hasil Amandemen, memang menjamin hak hidup setiap orang akan tetapi, secara tidak langsung konstitusi sama sekali tidak melarang adanya hukuman mati. Jika jaminan hak hidup dan hak lain yang tidak boleh dikurangi dalam kondisi apa pun telah dinyatakan dalam Pasal 281 ayat (1), maka Pasal 28j ayat (2) membatasi hak dan kebebasan manusia dengan pernyataan:

\footnotetext{
${ }^{25}$ Rahmanuddin Tomalili. Hukum Pidana. Yogyakarta: Deepublish, 2019, hlm. 208.

${ }^{26}$ Yahya Ahmad Zein. Problematika Hak Asasi Manusia (HAM). Yogyakarta: Liberty, 2012, hlm. 121.
} 
"Dengan menjalankan hak dan kebebasannya, setiap orang wajib tunduk kepada pembatasan yang telah di tetapkan dengan undang-undang dengan maksud semata-mata untuk menjamin pengakuan serta penghormatan atas hak dan kebebasan orang lain dan untuk memenuhi tuntutan yang adil sesuai dengan pertimbangan moral, nilai-nilai agama, keamanan dan ketertiban umum dalam suatu masyarakat yang demokratis".

Menjadi kewajiban negara untuk melaksanakan putusan hukuman mati yang telah berkekuatan hukum tetap. Langkah tegas tersebut perlu dilaksanakan agar tercipta keadilan dan kepastian hukum baik bagi korban, pelaku, maupun bagi masyarakat pada umumnya. Adanya kepastian dan keadilan diharapkan dapat memberikan manfaat, yaitu: munculnya efek jera dan daya tangkal. ${ }^{27}$ Pelaksanaan yang tidak berlarut-larut menjadi faktor utama bagi terlaksananya penegakan hukum di Indonesia, karena bukan hanya terkait soal kepastian hukum akan tetapi juga menyangkut soal wibawa dari sistem hukum yang berindikasi baik. ${ }^{28}$ Lambannya pelaksanaan hukuman mati tersebut pada hakekatnya disebabkan banyak faktor. Dalam konteks tersebut, sedikitnya ada lima faktor yang menyebabkan hal tersebut dapat terjadi, yaitu:

\section{A. Dari Aspek Yuridisnya}

Aspek yuridis merupakan aspek yang dominan dalam mempengaruhi lambat atau tidaknya eksekusi mati. Kaitannya dengan aspek tersebut, sebelum terpidana dieksekusi mati maka terlebih dahulu harus melewati beberapa tahapan yang semuanya itu di atur dalam peraturan perundang-undangan yang berbeda. Beberapa undang-undang terkait pelaksanaan hukuman mati ialah: UndangUndang Nomor 1 Tahun 1946 (UU No. 1 Tahun 1946) tentang Peraturan Hukum Pidana sebagaimana telah diubah dengan Undang-Undang Nomor 1 Tahun 1960 (UU No. 1 Tahun 1960) tentang Perubahan Kitab Undang-Undang Hukum Pidana (KUHAP), Undang-Undang Nomor 8 Tahun 1981 (UU No. 8 Tahun 1981) tentang Hukum Acara Pidana (KUHAP), Undang-Undang Nomor 22 Tahun 2002 (UU No. 22 Tahun 2002) tentang Grasi sebagaimana telah diubah dengan Undang-Undang Nomor 5 Tahun 2010 (UU No. 5 Tahun 2010) tentang Perubahan Atas UndangUndang Nomor 22 Tahun 2002 tentang Grasi dan Penetapan Presiden Nomor 2 Tahun 1964 (UU No. 2/PNPS/1964) tentang Tata-Cara Pelaksanaan Pidana Mati yang Dijatuhkan oleh Pengadilan di Lingkungan Peradilan Umum dan Militer sebagaimana telah diubah dengan Peraturan Kepala Kepolisian Negara Republik Indonesia Nomor 12 Tahun 2010 (Peraturan Polri No. 12 Tahun 2010) tentang Tata Cara Pelaksanaan Pidana Mati. Untuk itu pembahasan mengenai faktor yuridis yang menjadi salah satu faktornya, haruslah merujuk kepada berbagai peraturan Perundang-undangan tersebut, yaitu:

\section{Pasal 5 Peraturan Polri No. 12 Tahun 2010}

Dalam KUHP, ketentuan yang dapat mendorong lambannya pelaksanaan eksekusi mati yakni terdapat dalam Pasal 84 Ayat (4) ${ }^{29}$ KUHP, Pasal $5^{30}$ UU No. 2/PNPS/1964, dan ketentuan tersebut selaras dengan Pasal 5 Ayat (1) Peraturan Polri No. 12 Tahun 2010 yang mengatur bahwa:

\footnotetext{
${ }^{27}$ A. Istiqlal Assaad. "Hakikat Sanksi dalam Perspektif Hukum Pidana Indonesia dan Hukum Pidana Islam (Studi tentang Pidana Mati)." Al-Ishlah: Jurnal Ilmiah Hukum, Universitas Muslim Indonesia, vol. 19, no. 1 (2017): hlm. 127.

${ }^{28}$ Bambang Sugeng Rukmono. 2012. Op. Cit., hlm. 146.

${ }^{29}$ Kewenangan menjalankan pidana mati tidak terkena daluarsa.

${ }^{30}$ Menunggu pelaksanaan pidana mati, terpidana ditahan dalam penjara atau di tempat lain yang khusus ditunjuk oleh Jaksa Tinggi.
} 
"Persiapan dilakukan setelah adanya permintaan tertulis dari Kejaksaan kepada Kapolda, sesuai dengan daerah hukum pengadilan yang menjatuhkan putusan."

Selain Pasal tersebut di atas, masih ada ketentuan lain yang dapat menghambat pelaksanaan eksekusi yakni, ketentuan Pasal 6 Ayat (2) UU No. 2/PNPS/1964 yang mengatur tentang permintaan terakhir dari terpidana, adapun aturan tersebut menerangkan bahwa "apabila terpidana hendak mengemukakan sesuatu, maka keterangan atau pesannya itu diterima oleh Jaksa Tinggi/Jaksa tersebut". Kondisi demikian merupakan celah bagi aparat eksekutor untuk tidak segera mungkin melaksanakan eksekusi mati, apalagi pemenuhannya tersebut memerlukan waktu yang cukup lama, misalnya saja terpidana mati yang berasal dari luar negeri meminta bertemu dengan keluarganya, namun keluarganya tersebut belum sempat hadir karena masih dalam keadaan sakit. Disisi lain UU No.2/PNPS/1964 tidak memberikan batas waktu kapan permintaan terpidana tersebut harus dipenuhi. Adapun perubahan dalam Peraturan Polri No. 12 Tahun 2010, tidak lagi diatur tentang permintaan dari terpidana mati.

\section{Pasal 264 Ayat (3) UU No. 8 Tahun 1981/KUHAP}

KUHAP merupakan pedoman utama bagi kita semua dalam melaksanakan proses peradilan di indonesia. Di dalamnya diatur secara sistematis tentang sistem peradilan dan upaya hukum yang dapat di tempuh. Salah satu faktor penyebab lambannya eksekusi mati itu dilaksanakan yakni adanya proses upaya hukum yang ditempuh oleh terpidana mati berupa PK (Peninjauan Kembali).

Menurut Pasal 264 Ayat (3) KUHAP menyatakan bahwa permintaan PK tidak dibatasi dengan suatu jangka waktu tertentu, selain itu KUHAP juga tidak mengatur mengenai jangka waktu dari pemeriksaan PK tersebut. Ketentuan lain terdapat dalam Pasal 268 ayat (1) KUHAP menyatakan bahwa permintaan PK tidak dapat menangguhkan maupun menghentikan pelaksanaan hukuman mati. Namun dalam kasus hukuman mati, hal tersebut kurang selaras dengan ketentuan Pasal 3 dan Pasal 13 UU No. 5 Tahun 2010. Pasal 3 menyatakan "Permohonan Grasi tidak menunda pelaksanaan putusan pemidanaan bagi terpidana, kecuali dalam hal putusan pidana mati”.

Dengan adanya Putusan MK No. 34/PUU-XI/2013 yang membatalkan Pasal 268 ayat (3) KUHP, yang menentukan bahwa PK hanya dapat diajukan (1) satu kali saja. Dengan demikian, maka ketentuan dalam Pasal 268 ayat (3) KUHP tersebut tidak lagi memiliki kekuatan hukuman, sehingga dapat diartikan bahwa permintaan PK dapat diajukan berkali-kali atau lebih dari satu kali. Untuk mengantisipasi dan mencegah diajukannya permintaan PK berulang kali, maka MA mengeluarkan Surat Edaran No. 7 tahun 2014 yang menyatakan bahwa Putusan MK Nomor 34/PUU-XI/2013 tidak serta merta menghapuskan norma hukum yang mengatur PK hanya dapat dilakukan satu kali saja.

Sebab Pasal 268 ayat (3) KUHP dibatalkan MK, namun masih ada Pasal 24 ayat (2) UU No. 48 tahun 2009 dan Pasal 66 ayat (1) UU No. 5 tahun 2004 sebagaimana telah diubah dengan UU No. 5 tahun 2004 dan perubahan kedua dengan UU No. 3 tahun 2009 yang menyatakan bahwa permintaan PK hanya dapat diajukan satu kali. 


\section{Undang-Undang Grasi}

Berlakunya UU No. 22 tahun 2002 tentang adanya permohonan Grasi menjadi penyebab lambannya eksekusi mati seperti halnya dengan permohonan Grasi, karena undang-undang a quo tersebut membuka peluang diajukannya permohonan grasi berulang kali kepada Presiden. Hal ini dapat kita lihat dalam ketentuan Pasal 2 ayat (3) huruf a yang menyatakan bahwa permohonan grasi hanya dapat dilakukan satu kali, kecuali dalam hal terpidana yang pernah ditolak permohonan grasinya dan telah lewat waktu 2 tahun sejak tanggal permohonan grasi tersebut. Apabila kita rasionalkan, maka permohonan grasi tersebut bukan hanya dapat dilakukan untuk kedua kali akan tetapi dapat dilakukan berkali-kali sepanjang penolakan tersebut telah lebih dari 2 tahun, selain itu berdasarkan ketentuan Pasal 7 ayat (2) permohonan grasi tidak dibatasi oleh jangka waktu tertentu.

Grasi merupakan salah satu kewenangan presiden yang bersifat yudisial dalam rangka pemulihan keadilan yang terkait dengan putusan pengadilan. Sedangkan menurut ketentuan Pasal 1 angka 1 UU No. 2 Tahun 2002, sebagaimana telah diubah dengan UU No. 5 Tahun 2010:

"Grasi adalah pengampunan berupa perubahan, pengurangan, peringanan atau penghapusan pelaksanaan pidana kepada terpidana yang diberikan oleh Presiden".

\section{B. Kebijakan Pemerintah}

Kebijakan pemerintah yang menghendaki adanya penundaan kadang kala bukan hanya sekedar menunda akan tetapi juga dapat menghapuskan atau menggantikan hukuman mati tersebut dengan hukuman seumur hidup, hal tersebut merujuk pada ketentuan kebijakan pemidanaan berupa pengampunan dan penggantian hukuman.

Pembaharuan kebijakan pemidanaan berupa pengampunan dan penggantian hukuman yang diberikan oleh negara diperlukan sebagai sarana untuk mengganti hukuman mati bila masa daluarsa pelaksanaan hukuman mati tersebut sudah terlewati, namun terpidana tak kunjung dieksekusi.

\section{Lemahnya Koordinasi}

Lemahnya Koordinasi antara institusi yang terlibat dalam penanganan suatu perkara sering kali terjadi di indonesia, termasuk pula dalam hal pelaksanaan hukuman mati. Walaupun secara yuridis Kejaksaan di beri amanat oleh Undangundang sebagai pelaksana Putusan Pengadilan, namun faktanya dalam hal hukuman mati pelaksanaannya juga harus melibatkan institusi lain dalam hal ini: Kepolisian selaku pihak yang melaksanakan secara ril dan Lembaga Pemasyarakatan yang merupakan tempat terpidana ditahan selama menunggu datangnya eksekusi mati. Dengan demikian haruslah instansi-instansi terkait secara bersama membangun adanya koordinasi dalam hal pelaksanaan hukuman mati yang tidak berlarut-larut dan bertele-tele.

\section{KESIMPULAN}

Penegakan dan penerapan hukuman mati terhadap pelaku pembunuhan berencana harus diberlakukan, dengan alasan bahwa kasus-kasus pembunuhan yang dilakukan dinilai sangat keji dan kejam selain membunuh para pelaku kejahatan tersebut 
memutilasi dan memakan daging korbannya dengan dasar tersebut maka hukuman mati dinilai tidak bertentangan dengan HAM maupun hukum positif yang berlaku, karena aturan perundang-undangan tentang HAM secara tegas telah menerangkan tentang adanya pembatasan terhadap hak-hak tertentu dari seorang pelaku tindak pidana, yang mana hal tersebut tercantum dalam UU No. 39 Tahun 1999 tentang Hak Asasi Manusia, dan di dalam Pasal 340 KUHP tidak menjelaskan secara detail tentang quantitas (jumlah) korban yang timbul akibat pembunuhan tersebut. Jadi, di pidananya para pelaku tindak pidana kejahatan pembunuhan berencana merupakan salah satu bentuk wujud nyata dari penegakan hukum di masyarakat yang sesuai dengan tujuan hukum yaitu: kepastian, kemanfaatan dan keadilan. Sehingga masyarakat dapat hidup tenteram, aman, dan damai tanpa adanya bayang-bayang kekhawatiran akan kejahatan serupa dapat terulang kembali. Adanya beberapa faktor penghambat yang mempengaruhi penegakan hukuman mati pada dasarnya dapat memperlambat proses eksekusi sehingga menimbulkan kesan menunggu yang nantinya akan menjadi celah terhadap terpidana untuk dapat lepas dari jerat hukuman mati.

\section{SARAN}

Sebaiknya melakukan pembaharuan terhadap KUHP terkhusus lagi mengenai Pasal tentang Pembunuhan Berencana, agar dicantumkan dalam pasal ataupun penjelasannya tentang kualitas dan kuantitas yang didasarkan pada alternatif hukuman yang diberikan. Selanjutnya merekomendasikan mengenai batasan dan waktu dalam hal remisi dan pengajuan grasi terhadap hak terpidana mati yang melakukan kejahatan pembunuhan berencana karena hal tersebut dapat menjadi celah bagi para terpidana.

\section{UCAPAN TERIMA KASIH}

Penulis menghaturkan banyak terima kasih kepada jajaran Civitas akademika Universitas Muslim Indonesia yang telah mengizinkan, dan membantu dalam beragam hal kepada penulis untuk menyelesaikan penelitian akhir di Program Pasca Sarjana Universitas Muslim Indonesia, Makassar.

\section{DAFTAR PUSTAKA}

Abdullah, M. Zen. (2009). Pelaksanaan Hukuman Mati di Indonesia Telaah dalam Konteks Hak Asasi Manusia. Jurnal Ilmiah, Universitas Jambi.

Abdullah, Rozali \& Syamsir. (2002). Perkembangan HAM dan Keberadaan Peradilan HAM di Indonesia. Jakarta: Ghalia Indonesia.

Arba'i, Yon Artiono. (2012). Aku Menolak Hukuman Mati: Telaah Atas Penerapan Pidana Mati. Jakarta: Kepustakaan Populer Gramedia.

Ashri, Muhammad. (2018). Hak Asasi Manusia: Filosofi, Teori \& Instrumen Dasar. Makassar: CV. Social Politic Genius (SIGn).

Asnawi, Habib Shulton. (2012). Hak Asasi Manusia Islam dan Barat: Studi Kritik Hukum Pidana Islam dan Hukuman Mati. Supremasi Hukum, Vol. 1 No. 1, hlm. 25 - 48.

Assaad, A. Istiqlal. (2017). Hakikat Sanksi dalam Perspektif Hukum Pidana Indonesia dan Hukum Pidana Islam (Studi tentang Pidana Mati). Al-Ishlah: Jurnal Ilmiah Hukum, Universitas Muslim Indonesia, Vol. 19 No. 1, hlm. 119 - 135. 
Tim Redaksi BIP (Ed.) (2016). Undang-Undang Dasar Negara Republik Indonesia Tahun 1945. Jakarta: PT. Bhuana Ilmu Populer.

Gunakaya, Widiada. (2017). Hukum Hak Asasi Manusia. Yogyakarta: CV. Andi Offset.

Khanif, Al, Herlambang P. Wiratraman, \& Manunggal Kusuma Wardaya (Eds.). (2017). Hak Asasi Manusia: Dialektika Universalisme vs Relativisme di Indonesia. Yogyakarta: LKiS.

Lubis, Todung Mulya \& Alexander Lay. (2009). Kontroversi Hukuman Mati: Perbedaan Pendapat Hakim Konstitusi. Jakarta: Kompas.

Muhtaj, Majda El. (2017). Hak Asasi Manusia dalam Konstitusi Indonesia: Dari UUD 1945 Sampai dengan Perubahan UUD 1945 Tahun 2002. Jakarta: Kencana Prenada Media Group.

Pawennei, Mulyati \& Amiruddin. (2017). Hak Asasi Manusia: Sejarah dan Perkembangannya di Indonesia. Makassar: Alauddin University Press.

Penetapan Presiden Republik Indonesia Nomor 2 Tahun 1964 tentang Tata-Cara Pelaksanaan Pidana Mati yang Dijatuhkan oleh Pengadilan di Lingkungan Peradilan Umum dan Militer. Lembar Negara Republik Indonesia No. 38 Tahun 1964.

Peraturan Kepala Kepolisian Negara Republik Indonesia Nomor 12 Tahun 2010 tentang Tata Cara Pelaksanaan Pidana Mati. Berita Negara Republik Indonesia No. 242.

Putusan Uji Materi Mahkamah Konstitusi Republik Indonesia Nomor 34/PUU-XI/2013 Tahun 2013 tentang Pengujian Undang-Undang Nomor 8 Tahun 1981 tentang Hukum Acara Pidana terhadap Undang-Undang Dasar Negara Republik Indonesia Tahun 1945.

Rahardjo, Saptono (Ed.) (2017). 3 Kitab Undang-Undang Hukum: KUHPer, KUHP, KUHAP Beserta Penjelasannya. Jakarta: PT. Bhuana Ilmu Populer.

Rahim, Abdur, Asruddin Azwar, Muhammad Hafiz, \& Satrio Wirataru. (2015). Hukuman Mati: Problem Legalitas \& Kemanusiaan. Malang: Intrans Institute.

Reni, Hukman. (2015). Hukuman Mati di Indonesia. Jakarta: Swakelola.

Rukmono, Bambang Sugeng. (2012). Hakikat Pelaksanaan Hukuman Mati Ditinjau dari Perspektif Hak Asasi Manusia. Bandung: PT. Citra Aditya Bakti.

Silaban, Fernandes Edi Syahputra, Liza Erwina, \& Mahmud Mulyadi. (2013). Kebijakan Hukum Pidana terhadap Pengaturan Tindak Pidana Narkotika di Indonesia. Jurnal Mahupiki, Universitas Sumatera Utara, Vol. 1 No. 1.

Soejipto, Ani W. (Ed.) (2015). HAM dan Politik Internasional: Sebuah Pengantar. Jakarta: Yayasan Obor Indonesia.

Suhariyanto, Budi. (2015). Aspek Hukum Peninjauan Kembali Lebih dari Satu Kali dalam Perkara Pidana (Perspektif Penegakan Keadilan, Kepastian dan Kemanfaatan Hukum). Jurnal Hukum dan Peradilan, Mahkamah Agung RI, Vol. 4 No. 2, hlm. $335-350$. 
Sujatmoko, Andrey. (2015). Hukum HAM dan Hukum Humaniter. Jakarta: PT. Raja Grafindo Persada.

Surat Edaran Ketua Mahkamah Agung Republik Indonesia Nomor 7 Tahun 2014 tentang Pengajuan Permohonan Peninjauan Kembali dalam Perkara Pidana.

Tasrif, Yasin. (1971). Hak Asasi Manusia dalam Kerangka Hukum Nasional Indonesia. Makalah dipresentasikan pada Lokakarya Integrasi Materi HAM ke dalam Mata Kuliah Umum, di Semarang.

Tomalili, Rahmanuddin. (2019). Hukum Pidana. Yogyakarta: Deepublish.

Undang-Undang Republik Indonesia Nomor 1 Tahun 1946 tentang Peraturan Hukum Pidana.

Undang-Undang Republik Indonesia Nomor 1 Tahun 1960 tentang Perubahan Kitab Undang-Undang Hukum Pidana. Lembar Negara Republik Indonesia No. 1 Tahun 1960. Tambahan Lembar Negara No. 1921.

Undang-Undang Republik Indonesia Nomor 8 Tahun 1981 tentang Hukum Acara Pidana. Lembar Negara Republik Indonesia No. 76 Tahun 1981. Tambahan Lembar Negara No. 3209.

Undang-Undang Republik Indonesia Nomor 14 Tahun 1985 tentang Mahkamah Agung. Lembar Negara Republik Indonesia No. 73 Tahun 1985. Tambahan Lembar Negara No. 3316.

Undang-Undang Republik Indonesia Nomor 39 Tahun 1999 tentang Hak Asasi Manusia. Lembar Negara Republik Indonesia No. 165 Tahun 1999. Tambahan Lembar Negara No. 3886.

Undang-Undang Republik Indonesia Nomor 26 Tahun 2000 tentang Pengadilan Hak Asasi Manusia. Lembar Negara Republik Indonesia No. 208 Tahun 2000. Tambahan Lembar Negara No. 4026.

Undang-Undang Republik Indonesia Nomor 22 Tahun 2002 tentang Grasi. Lembar Negara Republik Indonesia No. 108 Tahun 2002. Tambahan Lembar Negara No. 4234.

Undang-Undang Republik Indonesia Nomor 5 Tahun 2004 tentang Perubahan UU 141985 tentang Mahkamah Agung. Lembar Negara Republik Indonesia No. 9 Tahun 2004. Tambahan Lembar Negara No. 4359.

Undang-Undang Republik Indonesia Nomor 3 Tahun 2009 tentang Perubahan Kedua Atas Undang-Undang Nomor 14 Tahun 1985 tentang Mahkamah Agung. Lembar Negara Republik Indonesia No. 3 Tahun 2009. Tambahan Lembar Negara No. 4958.

Undang-Undang Republik Indonesia Nomor 48 Tahun 2009 tentang Kekuasaan Kehakiman. Lembar Negara Republik Indonesia No. 157 Tahun 2009. Tambahan Lembar Negara No. 5076.

Undang-Undang Republik Indonesia Nomor 35 Tahun 2009 tentang Narkotika. Lembar Negara Republik Indonesia No. 143 Tahun 2009. Tambahan Lembar Negara No. 5062 . 
Undang-Undang Republik Indonesia Nomor 5 Tahun 2010 tentang Perubahan Atas Undang-Undang Nomor 22 Tahun 2002 tentang Grasi. Lembar Negara Republik Indonesia No. 100 Tahun 2010. Tambahan Lembar Negara No. 5150.

Undang-Undang Republik Indonesia Nomor 9 Tahun 2013 tentang Pencegahan dan Pemberantasan Tindak Pidana Pendanaan Terorisme. Lembar Negara Republik Indonesia No. 50 Tahun 2013. Tambahan Lembar Negara No. 5406.

Undang-Undang Dasar Negara Republik Indonesia Tahun 1945.

Waluyo, Bambang. (2015). Penegakan Hukum di Indonesia. Jakarta: Sinar Grafika.

Zein, Yahya Ahmad. (2012). Problematika Hak Asasi Manusia (HAM). Yogyakarta: Liberty. 